\title{
An Overview of Enterprising Theory
}

\author{
Devilal Sharma
}

ABSTRACT

National priority of the developing country for rapid economic development and reducing growing unemployment problems may be encouraging entrepreneurship developments and entrepreneurial characteristics to the younger people. Either through University education or through different government's policy it should be ensured that the investment friendly environment as well as youth's energy should be divert in entrepreneurial way to creating opportunity for self-economical development of the people. Scholars as well as academician's attention also should be concentrates on the matter. Thus the article focuses to fill that gap of national priority of developing nation like Nepal.

Key Words: Entrepreneurship, enterprise, opportunity, uncertainty, governance, judgments, decisionmaking, management, transaction cost theory, value.

\section{Introduction}

Entrepreneurship is concerned with the process of creating new enterprise or business firms. The entrepreneurial spirit has appeared as the engine of economic development (Agrawal, 2003). It has resulted millions of new enterprise in the world, which has served as the driving force for economic development. There is growing interest in the concept; however, no universally accepted definition is available. There is often great power in an interesting question. Like: Why do enterprise exist? And here, the study is struggling to understand the answer to this question for one particularly important class of enterprises, entrepreneurial ventures. This special issue brings together some leading scholars - scholars who study entrepreneurship and scholars who study the theory of the venture - to begin a conversation about why entrepreneurial venture exist. This represents a theoretical challenge for both these groups.

On the one hand, much of the received entrepreneurship literature is silent on why entrepreneurs would choose to organize a venture in order to exploit a market opportunity, as opposed to some other form of governance. The papers in this special issue focus directly on this issue. They argue that entrepreneurial opportunities can be exploited in a variety of ways and seek to understand the conditions under which organizing a venture is the most 
efficient way of exploiting a particular opportunity.

On the other hand, much of the received theory of the venture literature is silent on the unique organizing problems facing entrepreneurs. This silence seems to imply that entrepreneurial governance choices are no different than governance choices made in nonentrepreneurial settings. Some of the papers in this special issue do not make this assumption. Instead, they argue that entrepreneurs may face unique organizing challenges, challenges that are not well addressed in the current theory of the firm literature. Other papers in this issue argue that current theory can be extended to include entrepreneurial settings.

Thus, the papers in this special issue are germane to two audiences. For entrepreneurship scholars, these papers broaden the definition of what constitutes entrepreneurship and help identify when the venture, as opposed to other alternatives, is the best way to exploit an opportunity. For theory of the firm scholars, these papers either challenge the assumption that organizing decisions by entrepreneurs can be analyzed with the same theoretical tools as non-entrepreneurial organizing decisions or extend received theory to be more applicable in entrepreneurial settings.

\section{Identifying the Opportunities}

Opportunities to create new economic value exist because of competitive imperfections in factor or product markets (Barney, 1986; Shane and Venkataraman, 2000). These competitive imperfections may reflect changes in technology, demand, or other factor that individuals or groups in an economy attempt to exploit (Kirzner, 1973; Shane, 2003), or they may be created by the purposeful actions of these individuals or groups (Alvarez and Barney, 2006). Whatever the source of these competitive imperfections, their existence, per se, often only holds the potential for creating new economic value. The realization of this potential often requires additional economic activities, activities that sometimes require the organization of a firm and sometimes can be organized through other governance mechanisms, such as arbitrage and alliances. If a particular individual possesses all the resources - whether tangible or intangible - necessary to create economic wealth associated with a market opportunity, no additional economic organization is required to exploit this opportunity. For purposes of this discussion, when individuals possess all the resources necessary to exploit a market opportunity, and thus when no additional coordination through economic organization is required to create economic value, they are said to be engaging in arbitrage (Alvarez and Barney, 2007). 


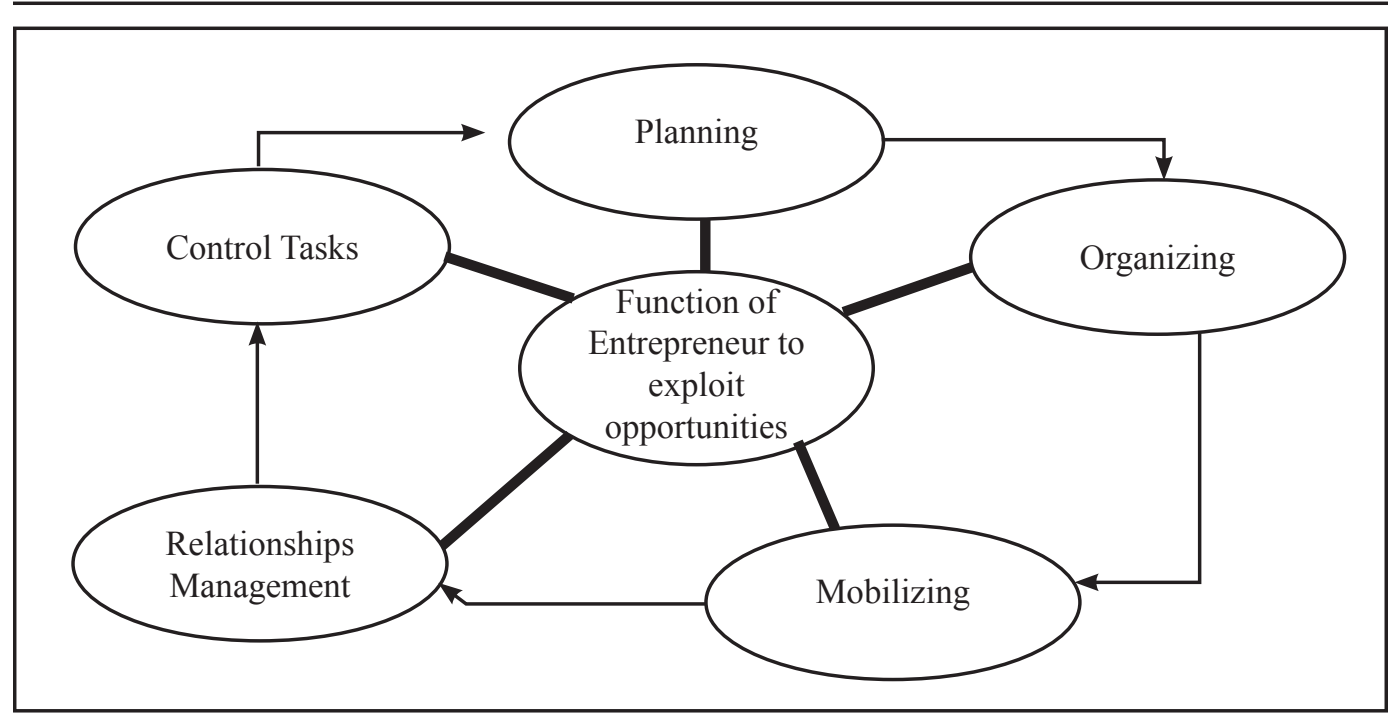

Figure: Function of Entrepreneur

In the phase of planning entrepreneur try to predetermine future through setting goals and developing business plan along with environmental scanning. If an individual does not possess all the resources required to exploit an opportunity, access to those resources will need to be obtained. This can be done in a variety of ways. For example, entrepreneurs can write market-like contracts with the owners of these resources to gain the access required to exploit an opportunity. Alternatively, entrepreneurs might form an alliance with the owners of these resources to gain access. Finally, entrepreneurs might decide that it is necessary to use hierarchical governance to gain access to these resources, and thus organize a firm to do so.

Thus, exploiting an opportunity might involve an entrepreneur in no economic organization, market-based economic organization, intermediate-market organization, or the organization of a firm. Failure to understand when these different approaches to exploiting opportunities will be chosen is an important limitation in the received entrepreneurship literature (Alvarez and Barney, 2007).

Not talking about these governance alternatives is a limitation in the entrepreneurship literature. Addressing issues of governance of markets, hierarchies, and hybrids such as alliances will broaden the scope of the literature in entrepreneurship. Second, understanding different governance options, when to use them, and how they apply in entrepreneurial contexts, helps entrepreneurs understand their full range of options.

\section{Different Styles of Governance the Enterprises}

Current theories of the venture assume that the decision-making context within 
which decisions about governance are made is risky, in the sense that the economic outcomes associated with an exchange can be known probabilistically when decisions about how to manage that exchange are made (Alvarez and Barney, 2004). Two such theories - transactions cost economics (Williamson, 1975, 1985) and incomplete contract theory (Grossman and Hart, 1986) - currently dominate discussions of when and how ventures are created.

Transactions cost theories of the venture focus on the role of hierarchical governance in reducing the threat of opportunism due to transaction specific investment in economic exchanges (Williamson, 1985). The central prediction of transactions cost economics is that economic actors will adopt hierarchical forms of governance - a venture - when the threat of opportunism due to transaction specific investment is very high. Incomplete contract theories of the venture, on the other hand, focus on how residual rights of control are assigned to parties in an exchange. The central prediction of this theory is that these residual rights will be assigned to that party in an exchange that has the most to gain from an exchange (Hart, 1995).

However, some entrepreneurial settings can be described as uncertain - where the economic consequences of an exchange cannot be known, even probabilistically, when decisions about how to organize that exchange are made. The received theory of the venture literature has not generally distinguished between risky and uncertain settings. It has been silent about whether or not the same decision making logic that applies for governance choices in risky settings applies to governance choices in uncertain settings (Alvarez and Barney, 2007).

\section{Role of Uncertainty in Governing Enterprises}

Transactions cost theory begins with the observation that economic actors will often find it in their self-interest to make specific investments to complete particular economic exchanges. However, making specific investments in a transaction increases the threat of opportunism - in particular, the threat that the party that makes these investments will not receive appropriate compensation for doing so (Williamson, 1975, 1985). Indeed, the inability to receive appropriate compensation for making specific investments can be so significant that economic actors will not make these investments in the first place (Klein et al., 1978).

Transactions cost theory suggests that hierarchical governance addresses the issue of opportunistic behaviour by bringing a problematic exchange within the boundaries of a firm where a manager can monitor and control the behaviour of all parties to that exchange. The ability to monitor and control behaviour within a firm to reduce the threat of opportunism in an exchange is known as 'managerial fiat'. The ability to exercise managerial fiat in a 
way that ensures the efficient operation of a firm, in turn, requires 'the boss' to have the information required to value the specific investments made by parties to an exchange, the information required to determine whether or not parties to an exchange are fulfilling their obligations, the information required to know how the profits generated by an exchange should be fairly distributed among parties to that exchange, and so forth. Indeed, the reason that hierarchy is thought to be able to control threats of opportunism in an exchange is that this form of governance makes it possible for those exercising managerial fiat to have sufficient information to manage an exchange efficiently (Williamson, 1975, 1985).

But what happens to the ability to exercise managerial fiat when the information required to exercise fiat does not exist - when the value of specific investments is not known, when the level and type of commitments required to complete an exchange are not known, and when the possible economic outcomes of an exchange are not known?

In these uncertain settings, how can 'the boss' efficiently monitor and control an exchange? More broadly, if it is difficult to efficiently exercise managerial fiat under conditions of uncertainty, on what basis then does an entrepreneur organize a firm in these settings? Such important questions as 'What resources should be coordinated in a transaction?', 'Who should exercise managerial fiat in a transaction?' 'On what basis should that fiat be exercised?', and 'Who should receive the residual benefits of engaging in an exchange?' are all problematic under conditions of uncertainty. Incomplete contract theory suggests that some economic exchanges occur in settings that are so complex that it is not possible to write enforceable contracts to manage these exchanges (Grossman and Hart, 1986). In such settings, it is not possible to specify, ex ante, which decisions should be made by whom in which situations to maximize the surplus generated by an economic exchange. The contracts that are the most difficult to specify ex ante concern those exchanges where the future is sufficiently complex that it cannot be anticipated. Ex post, at some future date, the complexity may be reduced and the non-specified elements of the contract may be specified. Ex ante, this often cannot be done (Alvarez and Barney, 2007).

One of the central propositions of this theory is that it is most efficient for those parties to an exchange who have the most to gain to have the residual rights of control in that exchange. The individual who has the most to gain has the greatest incentives to invest in this transaction in a way that maximizes its total value (Grossman and Hart, 1986). Those who benefit less from specific investments in an exchange will find it in their self interest to delegate residual rights of control to those who have the most to gain from an exchange, for these individuals have the strongest incentives to create the most value in an exchange. By assigning residual rights to those who will most benefit from an exchange, all parties 
to that exchange will be benefited when it is managed in a way that maximizes its value.

Current formulations of incomplete contract theory face similar difficulties in the face of uncertainty - defined as not knowing the future outcomes or the probabilities of those outcomes - as those faced by transactions cost economics. The information that is needed ex-ante to make a decision about who should have residual rights of control - information about who will benefit the most from an exchange - is not known, ex ante, under conditions of uncertainty. When parties to an exchange cannot know who should control residual rights in that exchange, how can they know how to organize a firm in this setting? And yet, decisions about firms - including decisions about who should hold residual rights of control - must sometimes be made under conditions of uncertainty (Alvarez and Barney, 2007).

Some of the papers in this special issue argue that there are important differences between risky and uncertain conditions with respect to how entrepreneurial exchanges are organized, and thus that current theories of the firm need to be augmented before they can be applied in uncertain entrepreneurial settings. Others argue that current theories can be extended to these uncertain settings. In either case, this is an important debate in understanding how entrepreneurs make governance choices.

\section{The Enterprising Theory}

The several scholars trying to answer the question of venture organization under conditions of uncertainty. The first paper is by Casson and Godley (2007) and applies a historical perspective to entrepreneurship and the theory of the venture. These authors address the reduction of uncertainty through the use of entrepreneurial judgment and decision-making by giving the reader a historical account of Singer as a significant innovator in the time period between 1880 and 1920. This paper illustrates how incorporating entrepreneurial judgment and decision-making into the innovative events of that time period led to the rise of the modern corporation. The next paper by Loasby (2007), pointedly addresses the absence of uncertainty in much of economics and in the theory of the venture literature in particular. Thus he too, suggests that the uncertainty is both contextual and in the judgment and decision-making of the entrepreneur. The third paper of this group is by Langlois (2007); he asks the provocative question, 'Does the firm exist because of entrepreneurship or indeed are entrepreneurial firms different from non-entrepreneurial ventures'?

The next set of papers more heavily rely on a subjectivist approach to the theory of the venture. The paper by Witt (2007) suggests that the use of a firm over a market is one of entrepreneurial choice and dependent upon the entrepreneur's vision of how to exploit an opportunity. The next paper by Zander (2007), suggests that the uncertainty is contextual but 
also understood at least incompletely by the entrepreneur. It is the difficulty of implementing new frameworks in often-unreceptive markets - markets where the participants are unable to accept or understand the entrepreneur's view that forces the entrepreneur to vertically integrate in order to organize the resources needed to further exploit what the entrepreneur perceives as an opportunity. The paper by Foss, Foss, Klein, and Klein (2007) explicitly defines entrepreneurship as the exercise of judgment over resource uses under uncertainty, and suggests that the entrepreneurial theory of the venture is one of capital ownership and organization by the entrepreneur. The paper by Kor, Mahoney, and Michael (2007) more formally develops a subjectivist theory of entrepreneurship and focuses heavily on individuals and their resources and skills. The final four papers in this issue vary in that they are much more context specific. Different scholars specifically suggest that the entrepreneur's objective is about maximizing wealth. The suggestion is that while the entrepreneur may indeed have a superior idea on how to add value to the upstream and downstream parts of the value chain, they may have problems in securing the needed cash to implement their ideas. Thus the firm in this view will depend on the entrepreneur's own theory of 'how to make money'. The paper by Audretsch and Keilbach (2007) focuses on the context in which an entrepreneur forms a firm. This paper suggests that it is the context and the knowledge available in a context that generates opportunities not individuals.

Thus in this view high rich knowledge context generates opportunities and low knowledge contexts generate fewer opportunities. The paper by Hsieh, Nickerson, and Zenger (2007) proposes an entrepreneurial theory of the firm from which opportunity discovery relates to interpretation draws from a problem-solving perspective. This perspective suggests that opportunity discovery requires the entrepreneur to select a problem to solve and then organize a search for solutions to the problem. The final paper, by Mahnke, Venzin, and Zahra (2007) addresses the uncertain context that is faced by multinational enterprises and how these enterprises use entrepreneurial judgment and decision-making in multilevel processes.

Owners of the enterprises were trying to address the impact of uncertainty by applying historical perspective of entrepreneurial theory, to exploit opportunities. Main sources of identifying opportunities are considered the trade fairs and exhibitions rather than research works in developing countries like Nepal. By the different papers and articles of the scholars in incorporating entrepreneurial judgments in decision making into the innovative events, that led to the establishment of modern corporations. Some of the papers in this special issue argue that there are important differences between risky and uncertain conditions with respect to how entrepreneurial exchanges are organized, and 
thus that current theories of the firm need to be augmented before they can be applied in uncertain entrepreneurial settings. Others argue that current theories can be extended to these uncertain settings. In either case, this is an important debate in understanding how entrepreneurs make governance choices.

\section{References}

Agrawal, G. R. (2003). Entrepreneurship Development in Nepal, M.K. Publishers: Kathmandu.

Alvarez, S. A. and Barney, J. B. (2007). 'The Entrepreneurial Theory of the Firm'. Journal of Management Studies. 44, 0022-2380.

Alvarez, S. A. and Barney, J. B. (2004). 'Organizing Rent Generation and Appropriation: toward a Theory of the Entrepreneurial Firm'. Journal of Business Venturing, 19, pp 621-35.

Alvarez, S. A. and Barney, J. (2005). 'How Entrepreneurs Organize Firms under Conditions of Uncertainty'. Journal of Management, 31, pp 776-93.

Alvarez, S. A. and Barney, J. B. (2006). Discovery and Creation: Alternative Theories of Entrepreneurial Action. Working Paper, Ohio State Fisher College Center for Entrepreneurship, Ohio State University, Columbus, $\mathrm{OH}$.

Audretsch, D. B. and Keilbach, M. (2007). 'The Theory of Knowledge Spillover entrepreneurship'. Journal of Management Studies, 44, pp 1242-54.

Barney, J. B. (1986). 'Strategic Factor Markets: Expectations, Luck, and Business Strategy'. Management Science, 32, pp 1231-41.

Casson, M. and Godley, A. (2007). 'Revisiting the Emergence of the Modern Business Enterprise: Entrepreneurship and the Singer Global Distribution System'. Journal of Management Studies, 44, pp 1064-77.

Foss, K., Foss, N. J., Klein, P. G. and Klein, S. K. (2007). 'The Entrepreneurial Organization of Heterogeneous Capital'. Journal of Management Studies, 44, 1165-86.

Grossman, S. and Hart, O. (1986). 'The Costs and Benefits of Ownership: A Theory of Vertical Integration'. Journal of Political Economy, 94, 691-719.

Hart, O. (1995). Firms, Contacts, and Financial Structure. Oxford: Clarendon Press.

Hsieh, C., Nickerson, J. A. and Zenger, T. R. (2007). 'Opportunity Discovery, Problem Solving, and A Theory of the Entrepreneurial Firm'. Journal of Management Studies, 44, 1255-77.

Kirzner, I. (1973). Competition and Entrepreneurship. Chicago, IL: University of Chicago Press.

Kor, Y. Y., Mahoney, J. T. and Michael, S. C. (2007). 'Resources, Capabilities, and Entrepreneurial Perceptions'. Journal of Management Studies, 44, 1187-213.

Langlois, R. N. (2007). 'The Entrepreneurial Theory of the Firm and the Theory of the Entrepreneurial Firm'. Journal of Management Studies, 44, 1107-24.

Loasby, B. J. (2007). 'A Cognitive Perspective on Entrepreneurship and the Firm'. Journal of Management Studies, 44, 1078-106.

Mahnke, V., Venzin, M. and Zahra, S. A. (2007). 'Governing Entrepreneurial Opportunity Recognition in MNEs: Aligning Interests and Cognition Under Uncertainty’. Journal of Management Studies, 44, $1278-98$.

Shane, S. (2003). A General Theory of Entrepreneurship. The Individual-Opportunity Nexus. Northampton, MA: Edward Elgar Publishing.

Shane, S. and Venkataraman, S. (2000). 'The Promise of Entrepreneurship as a Field of research'. Academy of Management Review, 25, 217.

Williamson, O. E. (1975). Markets and Hierarchies: Analysis and Antitrust Implications. New York: Free Press.

Williamson, O. E. (1985). The Economic Institutions of Capitalism. New York: Free Press.

Witt, U. (2007). 'Firms as Realizations of Entrepreneurial Visions'. Journal of Management Studies, 44, $1125-40$.

Zander, I. (2007). 'Do You See What I Mean? An Entrepreneurship Perspective on the Nature and Boundaries of the Firm'. Journal of Management Studies, 44, 1141-64. 